\title{
Population density of wheat aphid and its natural predators on different wheat varieties planting at different times under ecological zone Sheikhupura, Punjab, Pakistan
}

\author{
Muhammad Shahbaz ${ }^{*}$, Amna Palwasha ${ }^{2}$, Muhammad Riaz ${ }^{3}$, Faqir \\ Ahmad ${ }^{2}$, Zulfiqar Ali ${ }^{4}$, Usman Shakir ${ }^{2}$, Ghulam Nabi ${ }^{5}$, Aftab Hussain ${ }^{6}$, \\ Sher Muhammad ${ }^{7}$, Aftab Ahmad Khan ${ }^{8}$, Irfan Manzoor ${ }^{7}$, Saira Riaz ${ }^{9}$ \\ and Muhammad Anjum Ali ${ }^{10}$ \\ 1. Adaptive Research Farm Sheikupura, Punjab-Pakistan \\ 2. Pest Warning and Quality Control of Pesticides, Punjab, Lahore-Pakistan \\ 3. Pest Warning and Quality Control of Pesticides, Chakwal, Punjab-Pakistan \\ 4. Pest Warning and Quality Control of Pesticides, Sialkot, Punjab-Pakistan \\ 5. Ground-Nut Research Station, Attock, Punjab-Pakistan \\ 6. Agriculture Extension Sheikhupura, Punjab, Pakistan \\ 7. Department of Bioinformatics and Biotechnology, G.C. University Faisalabad-Pakistan \\ 8. Fodder Research Institute, Sargodha, Punjab, Pakistan \\ 9. Department of Entomology, University of Agriculture Faisalabad-Pakistan \\ 10. Director General of Agriculture (Extension \& Adaptive Research) Punjab, Lahore-Pakistan \\ *Corresponding author's email: shahbazssms2014@gmail.com \\ Citation \\ Muhammad Shahbaz, Amna Palwasha, Muhammad Riaz, Faqir Ahmad, Zulfiqar Ali, Usman Shakir, Ghulam Nabi, \\ Aftab Hussain, Sher Muhammad, Aftab Ahmad Khan, Irfan Manzoor, Saira Riaz and Muhammad Anjum Ali. \\ Population density of wheat aphid and its natural predators on different wheat varieties planting at different times \\ under ecological zone Sheikhupura, Punjab, Pakisatn. Pure and Applied Biology. Vol. 9, Issue 3, pp1780-1790. \\ http://dx.doi.org/10.19045/bspab.2020.90189
}

\begin{tabular}{llll}
\hline \hline Received: 20/02/2020 & Revised: 30/03/2020 & Accepted: 06/04/2020 & Online First: 20/04/2020 \\
\hline
\end{tabular}

\section{Abstract}

Three year field experiments were conducted to study the population density of wheat aphid and their beneficial fauna on different wheat varieties planted at different times at Adaptive Research Farm Sheikhupura, Pakistan in rice wheat cropping system. The experiment was laid out in split plot design in which varieties were replicated thrice in each planting date. Data for aphid population their predators, meteorological data, yield parameters and grain yield under different planting dates were recorded. Three years results revealed that in this ecological zone for wheat crop the planting dates $10^{\text {th }}$ to $30^{\text {th }}$ November performed better with respect to less attack of aphids, proper days required for maturity, number of grains per spike, number of tillers per $\mathrm{m}^{-2}$, thousand grains weight and grains yield. Late sown planting date causes reduction in yield due to reduce values of yield attributes and attack of aphid at growth stages while early sown date causes 
reduction in yield due to loss of grains weight by aphid feeding as the climatic conditions favors the development of aphids.

Key words: Aphids; Planting dates; Varieties; Wheat; Yield

\section{Introduction}

Wheat (Triticum aestivum L.) being a most important crop, grown on the principal area in Pakistan and has an important role in financial strength of the country [1]. It is the most leading grain crop and staple food for the individuals of Pakistan [2]. More than 35 $\%$ of the global population consumed wheat as an essential food [3]. Several biotic and abiotic factors are responsible for low yield of wheat per hectare in Pakistan as matched to other countries of the world $[4,5]$. Among insect pests of wheat, aphids are the major contributing factor in yield reduction in Pakistan. It is reported that about 35-40 \% yield loss due to wheat aphid by sucking cell sap [6] and its population density depends on abiotic factors [7]. In Pakistan during February- March aphid population rises and at the same time its predator's population also increases depends upon the local climatic conditions [8].

[9] reported that among aphid species Sitobion avenae (English grains aphid), Green bug (Rhopalosiphum padi) and bird cherry oat aphid (Schizaphis graminum) are common in Pakistan

Aphids invade the crop at diverse growth steps and both the nymphs and adults suck cell sap thus reducing the vigor of the plants. Honey dew excretion is often productive and smutty moulds generally convoy aphid's invasion which ultimately affects the rate of photosynthesis in plants. Aphids reproduce very quickly under encouraging situations on stems, leaves and inflorescence. [10] described that aphids draw sap from shoots and leaves that result in distortion and chlorosis of leaves. Due to negative effect and over reliance of pesticides is prohibited in Pakistan, several cultural control measures like intercropping of canola/sarsoon lines balance use of NPK fertilizers are the common practices for control of aphids.

Choice of suitable planting date is dynamic to get high production due to dissimilarity among the weather situations [11]. In rice wheat cropping pattern sowing of wheat is becoming late due to which sustaining high yield is much challenging.

The production damages affected by any of the aphid species was in the range of 35-40 percent at fifteen aphids per plant [12]. To stop heavy damages by aphids, numerous mechanisms have been developed containing physical chemical, biological, mechanical, cultural and host plant resistance. Pesticide treatment alone causes environment and health dangers in addition to pest resistance to chemicals due to their disproportionate and unselective uses. Studies on selection of different wheat genotypes for resistance against cereal aphids were conducted by various scientists; mainly the three principal aphid species, i.e. Sitobion avenae, Rhopalosiphum. padi and Schizaphis graminum [13]. Aphid predators including syrphid fly maggots, lacewings and lady beetles parasitize on all aphid species and are usually less discerning than parasitoids. Those flourish under high aphid densities and are therefore, not usually appropriate for use when aphid number is truncated [14]. Lady beetles are effective predators as those essential to consume many aphids per day for oviposition. Alternatively, Syrphid flies and its larvae are predaceous on aphids [15]. Additionally, Chrysopa spp (Neuroptera: Chrysopidae) are also insatiable predators of uncovered eggs and small larvae of all the aphids, mealy bugs and lepidopterous pests. It has a benefit above egg parasitoids that it nourishes on both larvae and eggs of pests and also its host range is considerable wider [13]. Intensity of aphids attack depends upon 
the local climatic conditions and stage of the crop. Several control measures like chemical, cultural, biological have been reported for control of aphids in wheat.

To assess the population density of wheat aphids on different wheat varieties planting at different times may be helpful in managing wheat aphids by optimizing suitable planting time under ecological zone of Sheikhupura. No local data is accessible on handling aphid population in wheat crop through integration of planting date, so, the present study was directed to assess the outcome of planting dates on aphid invasions to circumvent recounted losses to grain yield in wheat. Traditional practices like alteration in sowing time may be helpful in supervision wheat aphids keeping in assessment the indigenous agro climatic situations.

This study designed at inspecting the population subtleties of wheat aphids under the naturally occurring natural control mediators and also dedicated on finest planting period under local agro-climatic conditions of Adaptive Research Farm, Sheikhupura, and Punjab, Pakistan.

\section{Material and methods}

Experiment was arranged in split plot design and comprised of five different varieties and five different sowing dates conducted for three consecutive years $(2016-17,2017-18$ \& 2018-19) during rabi season. There were five main plots of planting dates and 15 sub plots of different varieties in each main plot during each year of crop season. Varieties were replicated in each sowing date and distance between replication was $2.0 \mathrm{ft}$. during each year. Individual subplot $28.5 \mathrm{~m}^{2}$ was maintained during each crop season. Total 15 subplots were maintained in one main plot (one planting date). At each sowing date, wheat seeds were disseminated by hand drill technique, using suggested seed rates $\left(1^{\text {st }}\right.$ to $20^{\text {th }}$ November, $1^{\text {st }}$ December and $11^{\text {th }}$ December planting dates, respectively). Standard agronomic practices were applied to raise uniformly the wheat crop grown on each sowing date. DAP (Diammonium phosphate; 46 percent phosphorus (P) and 18 percent nitrogen $(\mathrm{N})$ ) was applied as a basis of phosphorus. Urea (46 percent) was applied as a basis of N and MOP (60\%) was used as a basis of potash. All the application of potash and phosphorus were applied as basal at the time of sowing while $\mathrm{N}$ was applied in two equal breaches.

For statistics analysis, data was collected on aphid population and aphid infestation at 07 days interim at the appearance of aphid starting from $1^{\text {st }}$ week of February to end of March for the period of each crop season. There were eight counts regarding recordings of aphid populations of crop seasons 201617/2017-18/2018-19. During each specimen selection, ten wheat plants from each plot were arbitrarily selected. The number of aphids per tiller of each plant was documented as aphid density $[4,16]$. Number of aphids at bottom, middle and top leaf of the infected tiller and natural enemies per 05 plants were counted. The regular antagonists connected with the cereal aphids were calculated on each sampling date and adults, pupae, larvae and eggs per five plants were taken into description for predators. All the dissimilar phases of the Chrysopa spp. (Chrysoperla carnea), Syrphid flies (Ischiodon scutellaris) and lady beetles (Cocinela suptemntata) were together measured and calculated as Chrysopa, Syrphid flies and ladybird beetles correspondingly.

At the time of maturity $1 \mathrm{~m}^{2}$ areas from each plot was harvested and threshed for recording of grains yield. Data regarding relative humidity percent and temperature was recorded from the observatory on daily basis during the crop season. The parameters studied were exposed to analysis of variance and the means were related by the least substantial modification (LSD) at 0.05 probability level of significance [17]. 


\section{Results and discussion}

Data regarding density of mean aphid population per tiller of three consecutive crop seasons (2016-17, 2017-18 \& 2018-19) on five wheat varieties planted at five different times were presented in (Tables 1-5) which depict population dynamics of aphids in eight sampling counts in each planting date. It reveals that the aphids arrived in the $1^{\text {st }}$ week of February (04/2) with mean population of three years $1.33,1.13,0.59,0.19 \& 0.28$ aphids per tiller on the varieties Galaxy-2013, Faisalabad-2008, Ujala-2016, AARI-2011 and Punjab-2011 sown on planting dates 01 November, $11^{\text {th }}$ November, $21^{\text {st }}$ November, $1^{\text {st }}$ December and $11^{\text {th }}$ December respectively (Table 6). The population increased gradually till end February on the dates $1^{\text {st }}$ November, $11^{\text {th }}$ November and $11^{\text {th }}$ December. Significant increase in aphid population was noted from $1^{\text {st }}$ week of March to mid-March during each crop season. Peak aphids' population was recorded on all wheat varieties at all sowing dates during $1^{\text {st }}$ and second week of March with 44.21, 41.99, $37.86,35.26$ and 40.13 aphids per tiller on five planting dates respectively (average of three consecutive years). A significantly high population of aphids per tiller was recorded on all varieties sown during $1^{\text {st }}$ November and $11^{\text {th }}$ December dates during each crop season. Decline in aphid population was noted during $4^{\text {th }}$ week of March with a mean of $3.46,1.86,2.26,2.86 \& 6.51$ aphids per tiller on all wheat varieties planted at different times and came to end during $1^{\text {st }}$ week of April.

During the period $1^{\text {st }}$ week to mid-February maximum aphids were counted on varieties planted during $1^{\text {st }}$ November $\& 11^{\text {th }}$ December during each crop season. The period where minimum population was counted on wheat varieties planted on $11^{\text {th }}$ November, $20^{\text {th }}$ November and $1^{\text {st }}$ December.
During the mid-February to last week of February maximum 16.0 and 14.23 aphids were counted on planting dates $1^{\text {st }}$ November $\& 11^{\text {th }}$ December and minimum 3.19 and 3.33 aphids per tiller was counted on Wheat varieties planted at $21^{\text {st }}$ and $1^{\text {st }}$ December sowing times. Similarly $1^{\text {st }}$ week of March to mid-March and mid to last week of March high population of aphid was counted during each crop season on all planting dates. The population gradually increased and reached to its peak during the 2nd week of March, which slowly declined and came to an end during the 1st week of April. Two peaks of aphid was noted in whole crop season during each year of study period, highest population was noted from end February to March at temperature range from 18.11 to $22.54{ }^{\circ} \mathrm{C}$ and humidity from 68.6 to $52.1 \%$. The metrological data is given in (Table 7).

On average of three consecutive year of crop seasons data regarding varietal expression with respect to aphid infestation was presented in (Table 8) it depicts that maximum aphids per tillers were counted on varieties that planted on $1^{\text {st }}$ November and $11^{\text {th }}$ December while minimum aphids per tiller was counted on all varieties that planted during $11^{\text {th }}$ November and $21^{\text {st }}$ November (Table 8).

Keeping in view the sampling dates and different planting times that presented in (Table 9), it shows that data on average of three crop seasons among sampling dates peak aphid population was counted on sampling dates $25^{\text {th }} \mathrm{Feb}$. and $18^{\text {th }}$ March under all sowing dates, at this time the wheat crop under all sowing dates were at dissimilar periods. The huge number of aphid infestation happening during the $1^{\text {st }}$ week of February which progressively increased with the somatic stage of the plants in all crops established at dissimilar sowing time. 
Table 1. Comparison of mean aphid population per tiller on different wheat varieties planted on $1^{\text {st }}$ November an average of consecutive three year 2016-19

\begin{tabular}{|c|c|c|c|c|c|c|c|c|}
\hline \multirow{2}{*}{ Varieties } & \multicolumn{6}{|c|}{ Number of aphid counts from February to end March at week interval } \\
\cline { 2 - 9 } & $\mathbf{4 / 2}$ & $\mathbf{1 1 / 2}$ & $\mathbf{1 8 / 2}$ & $\mathbf{2 5 / 2}$ & $\mathbf{4 / 3}$ & $\mathbf{1 1 / 3}$ & $\mathbf{1 8 / 3}$ & $\mathbf{2 5 / 3}$ \\
\hline Galaxy 2013 & $0.66 \mathrm{a}$ & $3.00 \mathrm{~b}$ & $4.66 \mathrm{a}$ & $11.00 \mathrm{a}$ & $10.33 \mathrm{~b}$ & $40.00 \mathrm{a}$ & $48.33 \mathrm{ab}$ & $11.33 \mathrm{a}$ \\
\hline Faisalabad 2008 & $1.33 \mathrm{a}$ & $3.33 \mathrm{ab}$ & $3.00 \mathrm{~b}$ & $11.00 \mathrm{a}$ & $19.66 \mathrm{a}$ & $47.66 \mathrm{a}$ & $38.33 \mathrm{~b}$ & $1.33 \mathrm{a}$ \\
\hline Ujala 2016 & $1.66 \mathrm{a}$ & $5.00 \mathrm{a}$ & $4.33 \mathrm{ab}$ & $7.33 \mathrm{a}$ & $\begin{array}{c}14.00 \mathrm{a} \\
\mathrm{b}\end{array}$ & $43.33 \mathrm{a}$ & $40.00 \mathrm{ab}$ & $1.33 \mathrm{a}$ \\
\hline AARI- 2011 & $1.00 \mathrm{a}$ & $2.33 \mathrm{~b}$ & $3.66 \mathrm{ab}$ & $8.33 \mathrm{a}$ & $20.66 \mathrm{a}$ & $49.00 \mathrm{a}$ & $45.00 \mathrm{ab}$ & $1.33 \mathrm{a}$ \\
\hline Punjab 2011 & $2.00 \mathrm{a}$ & $4.00 \mathrm{ab}$ & $3.66 \mathrm{ab}$ & $10.66 \mathrm{a}$ & $19.66 \mathrm{a}$ & $38.33 \mathrm{a}$ & $50.00 \mathrm{a}$ & $2.00 \mathrm{a}$ \\
\hline LSD $(\mathrm{p} \leq 5 \%)$ & 1.49 & 1.68 & 1.53 & 6.75 & 6.92 & 11.33 & 10.74 & 0.97 \\
\hline
\end{tabular}

Table 2. Comparison of mean aphid population per tiller on different wheat varieties planted on $11^{\text {th }}$ November an average of consecutive three year 2016-19

\begin{tabular}{|c|c|c|c|c|c|c|c|c|}
\hline \multirow{2}{*}{ Varieties } & \multicolumn{6}{|c|}{ Number of aphid counts from February to end March at week interval } \\
\cline { 2 - 9 } & $\mathbf{4 / 2}$ & $\mathbf{1 1 / 2}$ & $\mathbf{1 8 / 2}$ & $\mathbf{2 5 / 2}$ & $\mathbf{4 / 3}$ & $\mathbf{1 1 / 3}$ & $\mathbf{1 8 / 3}$ & $\mathbf{2 5 / 3}$ \\
\hline Galaxy 2013 & $1.33 \mathrm{a}$ & $2.00 \mathrm{a}$ & $3.33 \mathrm{a}$ & $5.66 \mathrm{ab}$ & $13.33 \mathrm{ab}$ & $34.00 \mathrm{~b}$ & $45.00 \mathrm{a}$ & $2.33 \mathrm{ab}$ \\
\hline Faisalabad 2008 & $1.00 \mathrm{a}$ & $1.66 \mathrm{a}$ & $4.00 \mathrm{a}$ & $12.00 \mathrm{a}$ & $11.00 \mathrm{~b}$ & $45.33 \mathrm{a}$ & $36.66 \mathrm{a}$ & $1.00 \mathrm{c}$ \\
\hline Ujala 2016 & $0.66 \mathrm{a}$ & $1.33 \mathrm{a}$ & $4.66 \mathrm{a}$ & $10.66 \mathrm{ab}$ & $17.00 \mathrm{ab}$ & $39.66 \mathrm{ab}$ & $39.33 \mathrm{a}$ & $3.00 \mathrm{a}$ \\
\hline AARI- 2011 & $1.66 \mathrm{a}$ & $1.66 \mathrm{a}$ & $4.33 \mathrm{a}$ & $4.66 \mathrm{~b}$ & $20.66 \mathrm{a}$ & $33.33 \mathrm{~b}$ & $43.33 \mathrm{a}$ & $1.66 \mathrm{bc}$ \\
\hline Punjab 2011 & $1.00 \mathrm{a}$ & $2.33 \mathrm{a}$ & $5.66 \mathrm{a}$ & $8.00 \mathrm{ab}$ & $12.00 \mathrm{~b}$ & $41.00 \mathrm{ab}$ & $45.66 \mathrm{a}$ & $1.33 \mathrm{bc}$ \\
\hline LSD (p $\leq 5 \%)$ & 1.55 & 1.43 & 3.48 & 6.42 & 7.41 & 10.59 & 16.64 & 1.16 \\
\hline
\end{tabular}

Table 3. Comparison of mean aphid population per tiller on different wheat varieties planted on $21^{\text {st }}$ November an average of consecutive three year 2016-19

\begin{tabular}{|c|c|c|c|c|c|c|c|c|}
\hline \multirow{2}{*}{ Varieties } & \multicolumn{6}{|c|}{ Number of aphid counts from February to end March at week interval } \\
\cline { 2 - 9 } & $\mathbf{4 / 2}$ & $\mathbf{1 1 / 2}$ & $\mathbf{1 8 / 2}$ & $\mathbf{2 5 / 2}$ & $\mathbf{4 / 3}$ & $\mathbf{1 1 / 3}$ & $\mathbf{1 8 / 3}$ & $\mathbf{2 5 / 3}$ \\
\hline Galaxy 2013 & $0.66 \mathrm{a}$ & $1.00 \mathrm{~b}$ & $1.66 \mathrm{ab}$ & $3.00 \mathrm{a}$ & $9.33 \mathrm{~b}$ & $45.00 \mathrm{a}$ & $55.00 \mathrm{a}$ & $2.66 \mathrm{ab}$ \\
\hline Faisalabad 2008 & $0.33 \mathrm{a}$ & $1.00 \mathrm{~b}$ & $2.00 \mathrm{ab}$ & $3.00 \mathrm{a}$ & $11.00 \mathrm{~b}$ & $30.33 \mathrm{~b}$ & $24.66 \mathrm{~b}$ & $1.33 \mathrm{~b}$ \\
\hline Ujala 2016 & $0.66 \mathrm{a}$ & $1.00 \mathrm{~b}$ & $2.33 \mathrm{ab}$ & $4.00 \mathrm{a}$ & $16.33 \mathrm{a}$ & $32.66 \mathrm{~b}$ & $32.66 \mathrm{~b}$ & $3.66 \mathrm{a}$ \\
\hline AARI- 2011 & $1.00 \mathrm{a}$ & $1.66 \mathrm{ab}$ & $1.33 \mathrm{~b}$ & $3.33 \mathrm{a}$ & $11.33 \mathrm{~b}$ & $21.33 \mathrm{c}$ & $50.66 \mathrm{a}$ & $2.33 \mathrm{ab}$ \\
\hline Punjab 2011 & $0.33 \mathrm{a}$ & $2.00 \mathrm{a}$ & $3.00 \mathrm{a}$ & $2.66 \mathrm{a}$ & $6.00 \mathrm{c}$ & $46.66 \mathrm{a}$ & $26.33 \mathrm{~b}$ & $1.33 \mathrm{~b}$ \\
\hline LSD $(\mathrm{p} \leq 5 \%)$ & 1.00 & 0.97 & 1.55 & 1.75 & 2.94 & 8.20 & 16.59 & 2.06 \\
\hline
\end{tabular}

Table 4. Comparison of mean aphid population per tiller on different wheat varieties planted on $1^{\text {st }}$ December an average of consecutive three year 2016-19

\begin{tabular}{|c|c|c|c|c|c|c|c|c|}
\hline \multirow{2}{*}{ Varieties } & \multicolumn{6}{|c|}{ Number of aphid counts from February to end March at week interval } \\
\cline { 2 - 9 } & $\mathbf{4 / 2}$ & $\mathbf{1 1 / 2}$ & $\mathbf{1 8 / 2}$ & $\mathbf{2 5 / 2}$ & $\mathbf{4 / 3}$ & $\mathbf{1 1 / 3}$ & $\mathbf{1 8 / 3}$ & $\mathbf{2 5 / 3}$ \\
\hline Galaxy 2013 & $0.00 \mathrm{a}$ & $1.66 \mathrm{a}$ & $1.66 \mathrm{a}$ & $4.33 \mathrm{a}$ & $3.33 \mathrm{~d}$ & $64.66 \mathrm{a}$ & $47.33 \mathrm{a}$ & $5.00 \mathrm{a}$ \\
\hline Faisalabad- 2008 & $0.33 \mathrm{a}$ & $0.66 \mathrm{~b}$ & $0.66 \mathrm{~b}$ & $4.66 \mathrm{a}$ & $8.66 \mathrm{~b}$ & $30.33 \mathrm{~b}$ & $25.66 \mathrm{~b}$ & $1.33 \mathrm{~b}$ \\
\hline Ujala 2016 & $0.33 \mathrm{a}$ & $0.00 \mathrm{c}$ & $1.00 \mathrm{ab}$ & $3.00 \mathrm{ab}$ & $7.00 \mathrm{ab}$ & $17.33 \mathrm{~b}$ & $27.00 \mathrm{~b}$ & $5.33 \mathrm{a}$ \\
\hline AARI- 2011 & $0.33 \mathrm{a}$ & $1.00 \mathrm{~b}$ & $1.00 \mathrm{ab}$ & $2.33 \mathrm{~b}$ & $6.00 \mathrm{bc}$ & $25.00 \mathrm{~b}$ & $34.00 \mathrm{ab}$ & $1.33 \mathrm{~b}$ \\
\hline Punjab 2011 & $0.00 \mathrm{a}$ & $1.00 \mathrm{~b}$ & $0.66 \mathrm{~b}$ & $2.33 \mathrm{~b}$ & $4.33 \mathrm{~cd}$ & $85.00 \mathrm{a}$ & $42.33 \mathrm{ab}$ & $1.33 \mathrm{~b}$ \\
\hline LSD (p $\leq 5 \%)$ & 0.94 & 0.59 & 0.84 & 1.98 & 2.25 & 23.15 & 18.35 & 1.41 \\
\hline
\end{tabular}


Table 5. Comparison of mean aphid population per tiller on different wheat varieties planted on $11^{\text {th }}$ December an average of consecutive three year 2016-19

\begin{tabular}{|c|c|c|c|c|c|c|c|c|}
\hline \multirow{2}{*}{ Varieties } & \multicolumn{6}{|c|}{ Number of aphid counts from February to end March at week interval } \\
\cline { 2 - 9 } & $\mathbf{4 / 2}$ & $\mathbf{1 1 / 2}$ & $\mathbf{1 8 / 2}$ & $\mathbf{2 5 / 2}$ & $\mathbf{4 / 3}$ & $\mathbf{1 1 / 3}$ & $\mathbf{1 8 / 3}$ & $\mathbf{2 5 / 3}$ \\
\hline Galaxy-2013 & $0.00 \mathrm{a}$ & $10.00 \mathrm{a}$ & $9.00 \mathrm{a}$ & $22.66 \mathrm{a}$ & $20.00 \mathrm{a}$ & $52.33 \mathrm{a}$ & $39.33 \mathrm{a}$ & $6.66 \mathrm{a}$ \\
\hline Faisalabad-2008 & $0.20 \mathrm{a}$ & $6.66 \mathrm{ab}$ & $4.33 \mathrm{bc}$ & $13.33 \mathrm{~b}$ & $12.00 \mathrm{a}$ & $45.66 \mathrm{a}$ & $38.33 \mathrm{a}$ & $8.33 \mathrm{a}$ \\
\hline Ujala-2016 & $0.55 \mathrm{a}$ & $6.00 \mathrm{ab}$ & $6.33 \mathrm{~b}$ & $11.66 \mathrm{~b}$ & $11.00 \mathrm{a}$ & $40.00 \mathrm{a}$ & $40.00 \mathrm{a}$ & $6.66 \mathrm{a}$ \\
\hline Aari-2011 & $0.00 \mathrm{a}$ & $4.33 \mathrm{~b}$ & $4.33 \mathrm{bc}$ & $14.00 \mathrm{~b}$ & $14.33 \mathrm{a}$ & $55.00 \mathrm{a}$ & $40.00 \mathrm{a}$ & $4.33 \mathrm{a}$ \\
\hline Punjab-2011 & $0.66 \mathrm{a}$ & $4.00 \mathrm{~b}$ & $2.00 \mathrm{c}$ & $9.00 \mathrm{~b}$ & $13.33 \mathrm{a}$ & $44.00 \mathrm{a}$ & $43.00 \mathrm{a}$ & $6.60 \mathrm{a}$ \\
\hline LSD (p $\leq 5 \%)$ & 0.83 & 5.19 & 2.94 & 5.69 & 10.55 & 15.53 & 10.32 & 5.08 \\
\hline
\end{tabular}

Table 6. Trend of aphid Population per tiller at different sampling dates under five different planting times an average of consecutive three year 2016-19

\begin{tabular}{|c|c|c|c|c|c|c|c|c|}
\hline \multirow{2}{*}{ Sowing Dates } & \multicolumn{10}{|c|}{ Sampling Dates } \\
\cline { 2 - 9 } & $\mathbf{4 / 2}$ & $\mathbf{1 1 / 2}$ & $\mathbf{1 8 / 2}$ & $\mathbf{2 5 / 2}$ & $\mathbf{4 / 3}$ & $\mathbf{1 1 / 3}$ & $\mathbf{1 8 / 3}$ & $\mathbf{2 5 / 3}$ \\
\hline $1^{\text {st }}$ November & 1.33 & 3.50 & 6.43 & 16.0 & 17.0 & 43.53 & 44.21 & 3.46 \\
\hline $11^{\text {th }}$ November & 1.13 & 1.79 & 4.39 & 8.19 & 14.79 & 38.66 & 41.99 & 1.86 \\
\hline $21^{\text {st }}$ November & 0.59 & 1.33 & 2.06 & 3.19 & 10.80 & 35.19 & 37.86 & 2.26 \\
\hline $1^{\text {st }}$ December & 0.19 & 0.86 & 0.99 & 3.33 & 5.86 & 44.46 & 35.26 & 2.86 \\
\hline $11^{\text {th }}$ December & 0.28 & 6.19 & 5.19 & 14.13 & 14.23 & 47.39 & 40.13 & 6.51 \\
\hline
\end{tabular}

Table 7. Metrological data during wheat grown period at AR Farm Sheikhupura

\begin{tabular}{|c|c|c|c|c|c|c|c|c|c|}
\hline & \multicolumn{3}{|c|}{$\mathbf{2 0 1 6 - 1 7}$} & \multicolumn{3}{c|}{$\mathbf{2 0 1 7 - 1 8}$} & \multicolumn{3}{c|}{ 2018-19 } \\
\cline { 2 - 10 } & Jan. & Feb. & Mar. & Jan. & Feb. & Mar. & Jan. & Feb. & Mar. \\
\hline Max. Temp $\left({ }^{0} \mathrm{C}\right)$ & 18.7 & 25.4 & 27.0 & 17.4 & 20.0 & 26.5 & 18.4 & 18.1 & 22.5 \\
\hline Min. Temp $\left({ }^{0} \mathrm{C}\right)$ & 5.9 & 9.4 & 13.2 & 6.0 & 8.7 & 13.0 & 5.9 & 6.4 & 11.2 \\
\hline Humidity $(\%)$ & 70.0 & 65.4 & 50.2 & 71.0 & 63.0 & 55.0 & 70.7 & 68.6 & 52.1 \\
\hline Rainfall $(\mathrm{mm})$ & 1.50 & 0.08 & 0.33 & 1.5 & 3.5 & 1.0 & 1.12 & 3.01 & 0.29 \\
\hline
\end{tabular}

Table 8. Comparison of mean aphid Population per tiller on different wheat varieties planting at five different times (average of three consecutive years 2016-19)

\begin{tabular}{|c|c|c|c|c|c|}
\hline \multirow{2}{*}{ Varieties } & \multicolumn{5}{|c|}{ No. of aphids per tillers (Ave. of eight counts) at different date of sowing } \\
\cline { 2 - 6 } & $\mathbf{1}^{\text {st }}$ Nov. & $\mathbf{1 1}^{\text {th }}$ Nov. & $\mathbf{2 1}^{\text {st }}$ Nov. & $\mathbf{1}^{\text {st }}$ Dec. & $\mathbf{1 1}^{\text {th }}$ Dec. \\
\hline Galaxy-2013 & 22.3 & 15.2 & 13.8 & 15.8 & 17.8 \\
\hline Faisalabad-08 & 19.8 & 9.4 & 10.8 & 14.6 & 17.3 \\
\hline Ujala-2016 & 18.8 & 8.2 & 10.3 & 13.1 & 16.0 \\
\hline Aari-2011 & 17.0 & 10.0 & 9.7 & 13.0 & 14.3 \\
\hline Punjab-2011 & 17.9 & 13.0 & 9.7 & 12.3 & 14.6 \\
\hline
\end{tabular}

Table 9. Yield of Different Wheat Varieties Planted at different times (average of three years 2016-19)

\begin{tabular}{|c|c|c|c|c|c|}
\hline \multirow{2}{*}{ Varieties } & \multicolumn{5}{|c|}{ Yield kg ha $^{-\mathbf{1}}$} \\
\cline { 2 - 6 } & $\mathbf{0 1 . 1 1 . 2 0 1 8}$ & $\mathbf{1 1 . 1 1 . 2 0 1 8}$ & $\mathbf{2 1 . 1 1 . 2 0 1 8}$ & $\mathbf{0 1 . 1 2 . 2 0 1 8}$ & $\mathbf{1 1 . 1 2 . 2 0 1 8}$ \\
\hline Galaxy-2013 & $3327.7 \mathrm{a}$ & $3700.0 \mathrm{a}$ & $3645.5 \mathrm{a}$ & $3510.9 \mathrm{a}$ & 2776.7 \\
\hline Faisalabad-08 & $3287.6 \mathrm{a}$ & $3541.1 \mathrm{ab}$ & $3646.6 \mathrm{a}$ & $3395.5 \mathrm{~b}$ & 2850.0 \\
\hline Ujala-2016 & $3255.5 \mathrm{a}$ & $3605.5 \mathrm{~b}$ & $3560.0 \mathrm{~b}$ & $3453.2 \mathrm{a}$ & 2800.0 \\
\hline Aari-2011 & $2913.3 \mathrm{ab}$ & $3354.3 \mathrm{c}$ & $3282.7 \mathrm{bc}$ & $3150.0 \mathrm{c}$ & 2750.0 \\
\hline Punjab-2011 & $3033.3 \mathrm{~b}$ & $3461.0 \mathrm{c}$ & $3400.0 \mathrm{c}$ & $3325.3 \mathrm{ab}$ & 2820.3 \\
\hline LSD $(\mathrm{p} \leq 5 \%)$ & 111.15 & 84.20 & 98.73 & 103.13 & 43.82 \\
\hline
\end{tabular}


Sowing time exaggerated the plant development arrangement. In our findings, modification in sowing time transformed the development phases of wheat crop. This modification also exaggerated the aphid incidence on wheat crop. First time incidence of aphid was recorded at end of stem elongation $\left(1^{\text {st }}\right.$ November), $1^{\text {st }}$ node phase (11 ${ }^{\text {th }}$ November), stem elongation phase $\left(21^{\text {st }}\right.$ November), at start of stem elongation $\left(1^{\text {st }}\right.$ December) and at end of tillering phase $\left(11^{\text {th }}\right.$ December). [18] noted aphids on wheat plants at the stage of stems, leaves, heads and tillers. They also detected that aphids retained developing on the flag leaf and catching the developing awns and heads. This occurrence abridged photosynthetic doings, decrease in fertilization which consequences in low grain produce. At the peak of aphid population the crop growth stage was $1^{\text {st }}$ November at ears fully appear, $11^{\text {th }}$ November at ear initiation, $21^{\text {st }}$ November at booting, $1^{\text {st }}$ December at flag leaf and $11^{\text {th }}$ December at $2^{\text {nd }}$ node stage. Our results presented that greater population of aphids was due to tender crop growth stage that was perfect for aphid nurturing. Periodic population of aphid presented important modification among eight surveillance dates for three repeated years. These results are in conformism with that of [19], who stated that the aphid invasion on wheat crop trendy in the month of January touched it's highest during the 2nd week of March. Early sown crop plants had earing stage at this time crop was effected with aphids that infection leads to reduction in yield while optimum sowing was at progressive development phases than late propagated crops and thus crop presented an escape from aphid invasion. Time of invasion and crop development stage is a significant and important as the level of invasion on wheat crop for aphid vulnerability and its effect on grain produce. Data presented in (Table 6), depicted that at early counts more aphid population was documented on the sowing dates $1^{\text {st }}$ and $5^{\text {th }}$ while rare infestation of aphid was counted on wheat planted on $2^{\text {nd }}, 3^{\text {rd }}$ and $4^{\text {th }}$ dates. At mid of sampling dates $25 / 2$ and $4 / 3$ same level of aphid infestation was observed and recorded on all sowing dates except $2^{\text {nd }}, 3^{\text {rd }} \&$ $4^{\text {th }}$ and all varieties planted during each crop season while maximum population of aphids were counted on all varieties and planting dates during the sampling dates $11^{\text {th }}$ and $18^{\text {th }}$ March counting dates (Table 6). Aphid decline was documented on all sowing dates and varieties at the end of March during each crop season.

In this study maximum population was detected on late planted crop ( $11^{\text {th }}$ December $)$ and early sown crop ( $1^{\text {st }}$ November) during $3^{\text {rd }}$ week of March during each crop season. Overall seasonal aphid population was higher on late $\left(11^{\text {th }}\right.$ December $) \&$ early $\left(1^{\text {st }}\right.$ November) than that on timely sown crop $\left(11^{\text {th }}\right.$ to $30^{\text {th }}$ November) in rice-wheat cropping system. $[20,21]$ reported that aphids population reaches the peak in March and drops sharply at the beginning of April. It was also testified that highest aphid population was existent at milky stage while its peak dropped during dough period [22]. Results also supported with the observations of [23] who reported that aphid peak rests high in late planted crop and it is very less in well-timed planted crop, even lower than that of primary planted crop.

Results revealed that aphid population declined from end march this was due to rise in day and night temperature and appearance of beneficial fauna during each year in rice wheat cropping system. It was noted that grubs \& adults of lady bird beetle found actively feeding aphids during mid to end March during each cropping season. Our findings are in agreement with [24] who recounted that natural opponents of aphids might play a significant part in dropping pest population. Our results are similar to that of $[4,25]$, who described peak of aphid population during mid-February to mid- 
March. It may be due to quicker aphid breeding during the cold meteorological conditions. Our results are also agreed with that of $[16,21,26]$, who recorded aphid peak during March. [27] reported that at the end of March, rise in temperature, presence of beneficial fauna and humidity cause vegetation decline or removal of aphid invasion. These findings also supported the findings of our study. Our results are also similar to $[4,16]$ who reported failure in aphid population afterward mid-March due to the maturing of crop, rise in temperature and the outbreak of coccinellid beetles. The predators population per five plants at different sowing dates was also calculated in three consecutive years and found that with the increase of predators population, the aphid population decreases (Table 10). Our findings were also supported by [14].

Table 10. Predators population per five plants at different sowing dates an average of eight counts

\begin{tabular}{|c|c|c|c|}
\hline \multirow{2}{*}{ Planting Dates } & \multicolumn{3}{|c|}{ No. of Predators per five plants during three consecutive years 2016-19 } \\
\cline { 2 - 4 } & $\mathbf{2 0 1 6 - 1 7}$ & $\mathbf{2 0 1 7 - 1 8}$ & $\mathbf{2 0 1 8 - 1 9}$ \\
\hline $\mathbf{1}^{\text {st }}$ November & 7.4 & 7.0 & 5.1 \\
\hline $\mathbf{1 1}^{\text {th }}$ November & 7.2 & 8.0 & 4.0 \\
\hline $\mathbf{2 1}^{\text {st }}$ November & 6.2 & 5.6 & 7.3 \\
\hline $\mathbf{1}^{\text {st }}$ December & 6.0 & 4.9 & 5.2 \\
\hline $\mathbf{1 1}^{\text {th }}$ December & 8.4 & 5.8 & 6.5 \\
\hline
\end{tabular}

Our conclusions are buoyed by the conclusions of [28] who described that crop propagated in December suits more vulnerable for aphid species. [23] also testified that aphid invasion can be reduced by sowing of wheat primary in the period. These conclusions are in promise with our findings that less attack of aphid was noted on crop sown during mid to end November. [29] also recounted that delayed sowing of wheat crop develop witnessed with increased aphid population. Appropriately sown wheat crop is not only significant for improved crop growth but also have less strength of aphid invasion. Together early and late sowing of wheat crop causes decrease in production due to many biotic and abiotic reasons [30]. [31] reported maximum grain yield at timely sowing and lower grain produce in delayed sowing.

Data regarding impact of the aphid population on grain yield mean of three consecutive crop season of different varieties planted at five different times presented in (Table 8). It shows that maximum grain yield $3700.0,3541.0,3605.5,3354.3$ and 3461.0 $\mathrm{kg} \mathrm{ha}^{-1}$ was recorded from the varieties Galaxy-2013, Faisalabad-2008, Ujala-2016, AARI-2011 and Punjab-2011 respectively planted during $11^{\text {th }}$ November followed by $21^{\text {st }}$ November sown crop during each crop season while minimum 2776.7, 2850, $2800,2750 \& 2820.3 \mathrm{~kg} \mathrm{ha}^{-1}$ grain yield was obtained from Galaxy-2013, Faisalabad2008, Ujala-2016, AARI-2011 \& Punjab2011 respectively planted during $11^{\text {th }}$ December and the yield recorded from the varieties sown during $1^{\text {st }}$ November remained at $2^{\text {nd }}$ rank of minimum level. Among planting dates early sown $1^{\text {st }}$ November crop effected with wheat aphids and decreased yield by decreasing plant vigour, thousand grains weight and grains per spike. The planting date $11^{\text {th }}$ and $21^{\text {st }}$ November gave better yield than that of others while late sown planting date $11^{\text {th }}$ December did not perform well due to suffered with aphids, less number of productive tillers and grains per spike. [32] reported that high aphid population is the reason of yield loss in wheat. Postponement planting of crop cause decrease in development in addition to 
produce of crop, due to several reasons like aphid feeding, less number of tillers and reduced grains weight [33]. Feeding by aphids significant reduced plant growth, grains per spike, thousand grains weight and yield.

\section{Conclusion}

Change in planting dates influences the plant development in wheat crops. This alteration in plant development influences the strength of aphid invasion on wheat plants. Crops propagated during November have fewer aphid concentrations and have the aptitude to stand aphid feeding damage for their progressive plant growth causing greater grain produce as matched to crop propagated during December. From the study it is concluded that yield and aphid infestation were considerably exaggerated by planting dates. Postponement in propagating dates can influence severe decrease in development and produce. For optimum time of wheat sowing in rice-wheat cropping system is 10$30^{\text {th }}$ November keeping in view local climatic conditions. So it is suggested that wheat would be propagated at optimal propagating time for better production. It is recommended that avoid too early and too late sowing of wheat in Sheikhupura zone.

\section{Authors' contributions}

Conceived and designed the experiments: $M$ Shahbaz, Performed the experiments: M Shahbaz \& S Riaz, Analyzed the data: G Nabi, S Muhammad \& AA Khan, Contributed materials/ analysis/ tools: A Palwasha, M Riaz, F Ahmad, Z Ali, U Shakir, A Hussain \& MA Ali, Wrote the paper: M Shahbaz \& I Manzoor.

\section{References}

1. Anwar J, Hussain M, Ali MA, Hussain M, Saleem M, Subhani GM, Ahmad J \& Munir M (2011). Assessment of adaptability and stability of grain yield in bread wheat genotypes under different sowing times in Punjab. Pak J Bot 43: 1985-1993.
2. Hussain S, Khaliq A, Matloob A, Fahad S \& Tanveer A (2015). Interference and economic threshold level of little seed canary grass in wheat under different sowing times. Environ Sci Poll Res 22:441- 449 .

3. Khakwani AA, Dennett MD, Munir M \& Abid M (2012). Growth and yield response of wheat varieties to water stress at booting and anthesis stages of development. Pak J Bot 44(3): 879-886.

4. Khan AM, Khan AA, Afzal M \& Iqbal MS (2012). Wheat crop yield losses caused by aphid infestation. Biofertil Biopestic 3: 1-7.

5. Khattak, M.K., Riazuddin \& Anayatullah M (2007). Population dynamics of aphids (aphididae: homoptera) on different wheat cultivars and response of cultivars to aphids in respect of yield and yield related parameters. Pak J Zool 39: 109-115.

6. Aslam M, Razaq M, Akhter W, Faheem M \& Ahmad F (2005). Effect of sowing date of wheat on aphid (Schizaphis graminum Rondani) population. Pakistan Entomol 27: 79-82.

7. Wains MS, Jamil MW, Ali MA, Hussain M \& Anwar J (2014). Germplasm screening and incorporation of aphid resistance in bread wheat (Triticum aestivum L.). J Anim Pl Sci 24: 919-925.

8. Khan AA, Khan AM, Tahir HM, Afzal M \& Khaliq A et al. (2011). Effect of wheat cultivars on aphids and their predator populations. Afr J Biotechnol 10: 18399- 18402.

9. Shah AK, Ullah F, Hussain N, Saljoqi AUR, Hayat Y \& Sattar S (2006). Distribution pattern of the cereal aphids in the wheat growing areas of the province Khyber Pukhtunkhwa of Pakistan. Sarhad J Agric 22(14): 655659.

10. Akhtar IH \& Khaliq A 2003. Impact of plant phenology and coccinellid 
predators on the population dynamic of rose aphid Macrosiphum rosaeiformis Das (Aphididae: Homoptera) on rose. Asian J Pl Sci 2: 119-122.

11. Murungu, FS \& Madanzi T (2010). Seed priming, genotype and sowing date effects on emergence, growth and yield in a tropical low altitude area of Zimbabwe. African J Agric Res 5(17): 2341-2349.

12. Mirik M, Ansley J, Michels J \& Elliott N (2009). Grain and vegetative biomass reduction by the Russian wheat aphid in winter wheat. J Southw Ent 34: 131-139.

13. Khan SA (2005). Study on aphid distribution pattern and their natural enemies in wheat and maize crop. Ph.D. thesis, Department of Plant Protection, KP Agricultural University, Peshawar, pp 32-63.

14. Gillian F (2005). Factors to consider in using biocontrol agents for aphids predators.

http://www.search.gov.on.ca:8002/com pass.

15. Triplehorn CA \& Johnson NF (2005). Introduction to the study of insects. 7th Edition. Thomson Books 10 Davis Drive Belmont, CA 94002 USA.

16. Muhammad W, Nasir M, Abbas SK, Irshad M, Abbas MW, Nawaz A \& Rehman A (2013). Resistance pattern against aphid (Diuraphis noxia) in different wheat varieties/lines at district Layyah. Acad J Ent 6: 116-120.

17. Steel RGD Torrie JH \& Dickey DA (1997). Principles and procedures of statistics. A biometrical approach, $3^{\text {rd }}$ ed. McGraw Hill Inc., New York.

18. Akhtar LH, Hussain M, Iqbal RM, Amer M \& Tariq AH (2010). Losses in grain yield caused by Russian wheat aphid Diuraphis noxia (Mordvilko). Sarhad J Agric 26: 625-628.

19. Sattar S (2000). Impact of plant phenology of various wheat genotypes on aphid population and subsequent losses in wheat due to aphids. M.Sc (Hons) thesis, Department of Plant Protection, KP Agricultural University, Peshawar.

20. Wains MS, Aziz-ur-Rehman, Latif M \& Hussain M (2008) Aphid dynamics in wheat as affected by weather and crop planting time. J Agric Res 46: 361-366.

21. Zeb Q, Badshah H, Ali H, Shah RA \& Rehman M (2011). Population of aphids on different varieties/lines of wheat and their effect on yield and thousands grain weight. Sarhad J Agric 27: 443-450.

22. Aheer GM, Munir M \& Ali A (2006). Screening of wheat cultivars against aphids in ecological conditions of district Mandi Bahauddin. J agric Res 44: 5558.

23. Aslam M, Razaq M, Akhter W, Faheem M \& Ahmad F (2005) Effect of sowing date of wheat on aphid (Schizaphis gramium RONDANI) population. Pak Entomol 27: 79-82.

24. Bhambhro SA (2002). Threat of aphids to wheat crop DAWN-Business, the internet edition March18, 2002. http//www.DAWN.com

25. Manna SH (2002). Cereal aphids on wheat in new valley, natural enemies, seasonal activity of alate forms and susceptibility of certain varieties to natural infestation. Assiut J agric Sci 31: 287-297.

26. Abbas Q, Ahmad I, Shahid MA, Akhtar MF, Hussain M, Akram M \& Raza A (2014). Role of climatic factors on population fluctuation of aphids (Brevicoryne Brassicae, Myzus persicae and Lipaphis erysimi) on canola (Brassica napus) in Punjab, Pakistan. Pak J Nutr 13: 705-709.

27. Tabasum S, Noorka, IR, Afzal M \& Ali A (2012). Screening best adopted wheat lines against aphid (Schizaphis 
graminum Rondani)

population. Pakistan Entomol 34: 51-53.

28. Helmi A \& Rashwan R (2013). Effect of wheat cultivars and sown dates on aphid infestation in Egypt. Munis Ent Zool J 8: 825-830.

29. Shahzad MW, Razaq M, Hussain A, Yaseen M, Afzal M \& Mehmood MK (2013). Yield and yield components of wheat (Triticum aestivum) affected by aphid feeding and sowing time at Multan, Pakistan. Pak J Bot 45: 20052011.

30. Refay YA (2011). Yield and yield components parameters of bread wheat genotypes effected by sowing dates. Middle East J Sci Res 7(4): 484-489.
31. Tahir M, Ali A, Nadeem MA, Hussain A \& Khalid F (2009). Effect of different sowing dates on growth and yield of wheat genotypes in district Jhang, Pakistan. Pak J Life Soc Sci 7(1): 66-69

32. Wains MS, Rehman AU, Hussain M, Anwar J, Zulkiffal M \& Sabir W (2010). Aphid dynamics in relation to meteorological factors and various management practices in bread wheat. $J$ Plant Protect Res 50: 385-392.

33. Shahzad K, Bakht J, Ali SW, Shafi M \& Jabeen N (2002). Yield and yield components of various cultivars as effected by different sowing dates. Asian J Plant Sci 1(5): 522-525. 